\title{
RENCANA AKSI PENGEMBANGAN INDUSTRI KREATIF KULINER BERBASIS MEDIA ONLINE DI KOTA MALANG
}

\author{
Rofifah Yusadi, Budi Sugiarto Waluyo, Deni Agus Setyono \\ Jurusan Perencanaan Wilayah dan Kota Fakultas Teknik Universitas Brawijaya \\ Jalan Mayjen Haryono 167 Malang 65145 - Telp 567886 \\ E-mail: ovium13@gmail.com
}

\begin{abstract}
ABSTRAK
Sektor ekonomi kreatif merupakan sektor baru dalam struktur perekonomian Indonesia. Menurut Instruksi Presiden (Inpres) RI Nomor 6 Tahun 2009 tentang Pengembangan Ekonomi Kreatif, bahwa pemerintah telah mendukung kebijakan ekonomi kreatif melalui pengembangan industri kreatif. Salah satu aktivitas industri kreatif yang saat ini berkembang di Kota Malang adalah aktivitas kuliner online yang melibatkan pengguna/konsumen lebih dari 160.000 pada tahun 2013. Namun, keberadaan aktivitas kuliner online belum teridentifikasi datanya oleh pemerintah dan belum terdapat upaya fasilitasi pengembangan aktivitas kreatif tersebut dalam agenda pembangunan daerah. Oleh karena itu, penelitian dilakukan untuk mengidentifikasi karakteristik kuliner online dan menyusun rencana aksi pengembangan sektor kuliner online. Hasil analisis aktor menunjukkan bahwa Dinas Perindustrian Kota Malang menjadi aktor utama pelaku perencanaan strategis. Hasil analisa terhadap 96 pelaku kuliner online menggambarkan terdapat 3 faktor yang menyebabkan pergeseran paradigma yaitu perubahan sistem produksi, distribusi, dan pemasaran produk yang digunakan sebagai dasar penyusunan rencana aksi berbasis value proposition yakni operational excellences. Penelitian ini menghasilkan 1 visi yang dijabarkan melalui 3 misi dengan 10 strategi pengembangan yang dirincikan menjadi 22 rencana aksi pengembangan industri kreatif kuliner online di Kota Malang.
\end{abstract}

Kata Kunci: Industri Kreatif, Kuliner Online, Perencanaan Strategis, Operational Excellence

\section{ABSTRACT}

Creative economy is a new sector in the Indonesian economy. Based on Presidential Instruction (Inpres) Number 6 Year 2009 on Creative Economy Development, the government has supported creative economy policy through creative industry. One of the creative industries sub-sector in Malang is culinary culinary that reach 160.000 users in 2013. However, the existence of online culinary has not been recorded by the government and there has been no study of local product development in RPJMD. Therefore, this research is needed related to the identification of online culinary characteristics and the preparation of action plans of its development. Based on stakeholders analsis, Industrial and Trading Department become the executant of strategic planning. Based on the results of research on 96 units of online culinary, there are 3 factors of value shift which is changes in production, distribution, and marketing processes that can be used as the basis for action plans based on value proposition that is operational excellence. This research comes out into 1 vision, 3 missions with 10 different strategies and 22 action plans for the development of online culinary creative industry in Malang City.

Keywords: Creative Industry, Online Culinary, Strategic Palnning, Operational Excellence

\section{PENDAHULUAN}

Sektor ekonomi kreatif merupakan sektor baru yang membentuk struktur perekonomian Indonesia. Menurut Instruksi Presiden (Inpres) Nomor 6 Tahun 2009 tentang Pengembangan Ekonomi Kreatif, pemerintah telah mendukung kebijakan pengembangan ekonomi kreatif dalam tujuan untuk meningkatkan kegiatan ekonomi masyarakat, yakni dengan menciptakan aktivitas industri kreatif yang meliputi 16 subsektor. Kota Malang sebagai kota terbesar kedua di Provinsi Jawa Timur dikenal sebagai kota pendidikan dan kota wisata. Kota Malang juga mulai dikembangkan sebagai salah satu kota kreatif (creative city) Indonesia. Berbagai kegiatan industri kreatif dikembangkan untuk menunjang predikat Kota Malang tersebut, seperti aktivitas industri kreatif yang bergerak pada sub sektor kuliner/olah makanan terutama dikarenakan aktivitas kreatif kuliner di Kota Malang memiliki peluang yang cukup besar untuk dikembangkan. Perkembangan Kota Malang didukung dengan tingkat pertumbuhan ekonomi yang rata-rata mencapai $6 \%$ setiap tahun dengan kontribusi terbesar terhadap PDRB setiap tahunnya berasal dari sektor industri pengolahan serta sektor perdagangan, hotel dan restoran (BPS Kota Malang, 2010). Salah satu cabang aktivitas industri kreatif kuliner adalah aktivitas kuliner online yang perkembangannya diindikasikan dari potensi jumlah pengguna internet di Kota Malang yang lebih dari 160.000 jiwa pada tahun 2013 (Dinas Komunikasi dan Informatika). Oleh karena itu, penelitian ini dilakukan untuk mengidentifikasi karakteristik industri kreatif kuliner berbasis transaksi online di Kota Malang dan menyusun rencana aksi pengembangan dengan basis aktor pemerintah. Penyusunan 
rencana pengembangan kuliner berbasis aktivitas online dilakukan dengan menggunakan metode perencanaan strategis sebagai usaha yang sistematis untuk menentukan tujuan, aturan, dan strategi yang melibatkan pembuatan rencana yang detail untuk megimplementasikan aturan dan strategi untuk mencapai tujuan utama (Steiner dalam Arasa, 2013).

\section{TINJAUAN PUSTAKA \\ Industri Kreatif}

PERPRES No. 28/2008 tentang

kebijakan industri nasional mendefinisikan industri kreatif sebagai industri yang mengkombinasikan kreatifitas untuk menghasilkan kekayaan dan lapangan kerja. Ciri industri kreatif adalah peran strategis manusia melalui kreativitas, keahlian, dan bakatnya.

\section{Klasifikasi Kuliner}

\section{Makanan Indonesia}

Makanan Indonesia terdiri atas hidangan pokok, lauk pauk, sayur, dan sambal (Handayani, 2011).

\section{Makanan Barat (Western Food)}

Makanan utama yang biasa menjadi favorit dari western food yakni steak yang bisa dimasak dengan pilihan setengah matang ataupun sangat matang, hingga makanan penutup yang biasanya berbentuk hidangan manis seperti apple pie dengan es krim yang berguna untuk menetralisir rasa dari makanan pembuka dan makanan utama yang gurih (Soekresno, 2000).

\section{Makanan Asia}

Makanan Asia memiliki ciri khas yaitu menggunakan bumbu bawang putih, jahe, minyak wijen, dan kecap asin di dalam masakannya (Chen, 2015).

\section{Makanan Penutup (Desserts)}

Desserts atau makanan penutup mempunyai ciri yaitu cookies atau cakes yang mempunyai rasa manis (Brown, 2015).

\section{Karakteristik Kuliner}

\section{Sumber Daya Manusia}

Sumber daya manusia kreatif adalah orangorang yang menciptakan ide-ide baru, teknologi dan metode baru, serta kandungan baru (new content), (Departemen Perdagangan 2008:20).

\section{Sistem Produksi}

Sistem produksi terdiri atas elemen struktural yang terdiri dari bahan (material), mesin atau peralatan, tenaga kerja, modal, energi, informasi, dan lain lain (Rahmasari, 2011).

\section{Pemasaran}

Menurut Kennedy dalam Tjiptono (2008) pemasaran adalah sekumpulan rancangan kegiatan yang saling terkait untuk mengenali kebutuhan konsumen dan mengembangkan, mendistribusikan, mempromosikan, serta menetapkan harga yang tepat dari sebuah produk dan layanan untuk mencapai kepuasan konsumen yang bertujuan untuk menghasilkan keuntungan.

Aktor Pengembangan (Quadruple Helix)

Quadruple Helix merupakan kolaborasi empat aktor yaitu pemerintah, bisnis, akademisi, dan komunitas yang berperan mendorong tumbuhnya inovasi (Oscar dalam Mulyana, 2014).

\section{Pemerintah}

Peran pemeritah adalah sebagai lembaga yang memilliki otoritas pengembangan industri kreatif.

\section{Akademisi}

Akademisi memainkan peran kunci dalam pengembangan inovasi dan teknologi yang akan ditransfer pada pihak pelaku bisnis industri kreatif.

\section{Bisnis}

Aktor bisnis diperlukan untuk memperkenalkan praktek dan prosedur yang inovatif dalam pengembangan kewirausahaan.

\section{Komunitas}

Komunitas berperan sebagai pendukung dalam perubahan gaya hidup, perilaku konsumsi, dan partisipasi dalam pengaturan kelembagaan yang memacu inovasi sosial dan kelembagaan.

\section{Value Proposition}

Value proposition adalah nilai atau manfaat yang ditawarkan kepada pelanggan yang terdiri atas tiga pilar yaitu operational excellence, customer intimacy, dan product leadership (Ostewalder dalam Nurmanisa, 2016).

\section{METODE}

\section{Populasi Penelitian}

Populasi dalam penelitian ini adalah pelaku industri kreatif kuliner online yang ada di Kota Malang yakni sebanyak 96. Selain itu juga terdapat Pemerintah Kota Malang, Komunitas Kuliner Online Kota Malang, dan Akademisi/ahli di bidang industri kreatif.

\section{Metode Analisis}

\section{Analisis PESTEL}

Aspek yang dibahas dalam analisis PESTEL meliputi aspek Politik yaitu isu lingkungan dan kebijakan pemerintah; aspek Ekonomi yaitu tren ekonomi lokal/dalam negeri, tren aliran pasar dan distribusi, pelanggan; aspek Sosial yaitu tenaga kerja, perubahan gaya hidup, pendidikan, dan kesejahteraan; aspek Teknologi yaitu fokus 
pemerintah dalam industri pada kemajuan teknologi yaitu biaya dan penggunaan teknologi dan dampak dari perubahan teknologi serta aspek Lingkungan yaitu limbah produksi dan faktor hukum/legal yaitu kebijakan pekerja (Team FME, 2013).

\section{Analisis Linkage System}

Analisis yang digunakan dalam mengidentifikasi linkage system adalah survey keterhubungan sistem produksi-pada suatu kategori industri di suatu daerah dan di daerah lainnya, khususnya daerah paling dekat. Informasi survei yang didapat adalah mengenai output dari proses produksi (forward production linkages) dan informasi mengenai input dari proses produksi (backward production linkages).

\section{Analisis Bauran Pemasaran}

Bauran pemasaran merupakan satu dari sekian konsep yang paling universal yang telah dikembangkan dalam pemasaran dan sebagian besar memusatkan pada empat komponen kunci, yaitu produk, harga, promosi, dan lokasi. Kotler dalam Hermawan (2015) menggolongkan produk berdasar sudut pandang yaitu barang tidak tahan lama (indurable goods) dan barang tahan lama (durable goods). Penetapan harga dipengaruhi oleh permintaan produk, target pangsa pasar, reaksi pesaing, strategi penetapan harga, bagian lain di luar bauran pemasaran dan biaya operasional. Tujuan utama dari kegiatan promosi adalah menginformasikan, mempengaruhi dan membujuk, serta mengingatkan konsumen. Place dalam elemen bauran pemasaran ini adalah lokasi. Lokasi merupakan keputusan organisasi mengenai tempat operasinya dengan semua kegiatan-kegiatan organisasi.

\section{Analisis SWOT}

Analisis SWOT adalah metode yang digunakan untuk mendefinisikan kekuatan, kelemahan, peluang, dan ancaman pada masing-masing strategi yang kemudian dirangkum sebagai rencana aksi pengembangan.

\section{PEMBAHASAN}

\section{Karakteristik Industri Kreatif Kuliner \\ Berbasis Media Online di Kota Malang}

Pelaku industri kuliner online terdiri dari

2 (dua) jenis, yaitu produsen kuliner sekaligus pemasar sebanyak $95 \%$ atau 91 unit serta terdapat pelaku yang hanya berperan sebagai pemasar/reseller sebanyak $5 \%$ atau 5 unit. Berikut jumlah pelaku industri kreatif kuliner berbasis media online di Kota Malang berdasar jenis produk yang dihasilkan:
Tabel 1 Jumlah Pelaku Kuliner Online Berdasar Jenis Produk

\begin{tabular}{|c|c|c|}
\hline No & Jenis Produk & Jumlah Pelaku \\
\hline 1. & Makanan Indonesia & 26 \\
\hline 2. & Western Food & 15 \\
\hline 3 . & Makanan Asia & 4 \\
\hline 4. & Desserts & 34 \\
\hline 5. & $\begin{array}{l}\text { Makanan Indonesia, Western } \\
\text { Food, Makanan Asia, dan } \\
\text { Desserts }\end{array}$ & 2 \\
\hline 6. & $\begin{array}{l}\text { Makanan Indonesia, Western } \\
\text { Food, dan Desserts }\end{array}$ & 2 \\
\hline 7. & $\begin{array}{l}\text { Makanan Indonesia, Western } \\
\text { Food, dan Makanan Asia }\end{array}$ & 1 \\
\hline 8. & Makanan Indonesia dan Desserts & 3 \\
\hline 9. & $\begin{array}{l}\text { Makanan Indonesia dan Western } \\
\text { Food }\end{array}$ & 4 \\
\hline 10. & $\begin{array}{l}\text { Makanan Indonesia dan Makanan } \\
\text { Asia }\end{array}$ & 3 \\
\hline 11. & Makanan Asia Dan Desserts & 2 \\
\hline & Total & 96 \\
\hline
\end{tabular}

\section{Aspek Teknologi}

Penggunaan alat/teknologi bertujuan untuk mempermudah dan mempercepat proses produksi, serta dapat meningkatkan jumlah produk yang dihasilkan. Jenis teknologi yang digunakan pada proses produksi yaitu food processor, slow cooker, mixer heavy duty, spinner, dan cold press juicer.

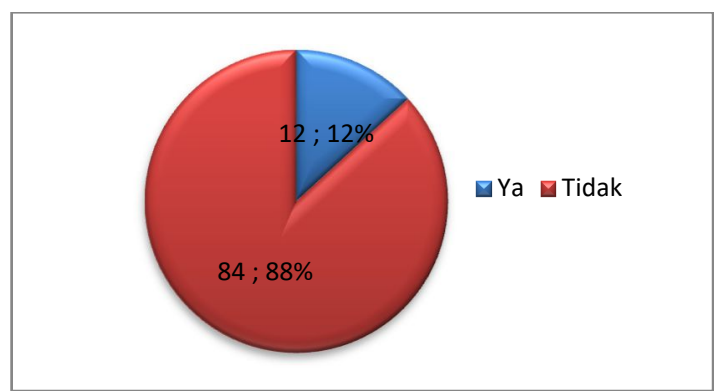

Gambar 1. Penggunaan Teknologi pada Proses Produksi

Bentuk dukungan dari stakeholder terhadap aspek ini adalah kegiatan pengenalan teknologi terapan dalam proses produksi kepada pelaku industri kreatif dan memberikan investasi teknologi tersebut kepada beberapa unit industri kreatif.

\section{Aspek Sumber Daya}

Ketersediaan sumber daya atau bahan baku dapat mempengaruhi kapasitas produksi dan keberlanjutan industri kreatif kuliner online. Berikut diuraikan sumber bahan baku produksi yang diusahakan oleh 96 pelaku industri kreatif kuliner berbasis media online di Kota Malang. 


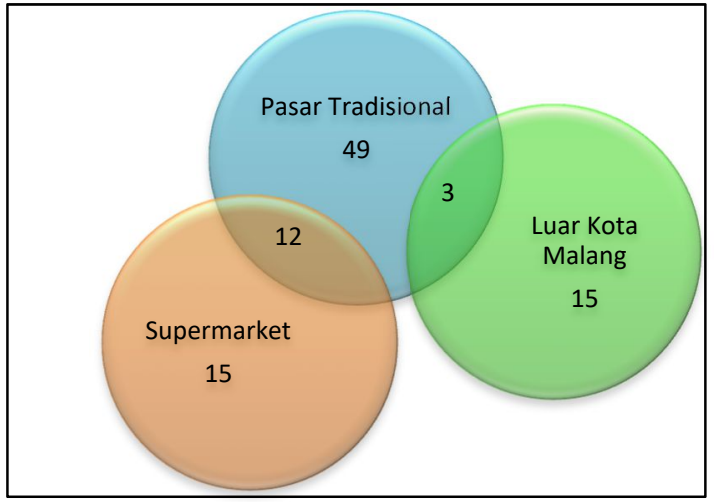

Gambar 2. Sumber Bahan Baku Produk

Berdasar analisa diketahui sebanyak 64 pelaku kuliner online mendapatkan bahan baku produksinya langsung dari pasar tradisional karena harga bahan baku lebih terjangkau dan tersedia dalam jumlah yang lebih banyak dan lebih segar. Kemudian sebanyak 27 pelaku kuliner online mendapatkan bahan baku produk dari Supermarket seperti Giant, Avia, Superindo, Loka, Hypermart, Persada Swalayan, Prima Rasa, dan Sardo serta juga dari luar Kota Malang dikarenakan beberapa jenis bahan baku tidak tersedia di pasar lokal Malang. Adapun untuk pelaku kuliner online yang kegiatannya hanya memasarkan produk (reseller/ dropship) maka sebagian besar memperoleh produknya dari luar kota, seperti Tasikmalaya, Surabaya, Medan, dan Jakarta dengan membeli produk jadi dalam jumlah/porsi yang cukup banyak dan kemudian dipasarkan langsung ke konsumen tanpa melakukan kegiatan pengolahan lebih lanjut.

Industri kreatif kuliner online ini juga didukung dengan keberadaan tenaga kerja dengan keahlian khusus seperti koki untuk menjamin kualitas produk yang dihasilkan. Berikut diagram keberadaan tenaga kerja ahli atau koki pada unit industri yang ada.

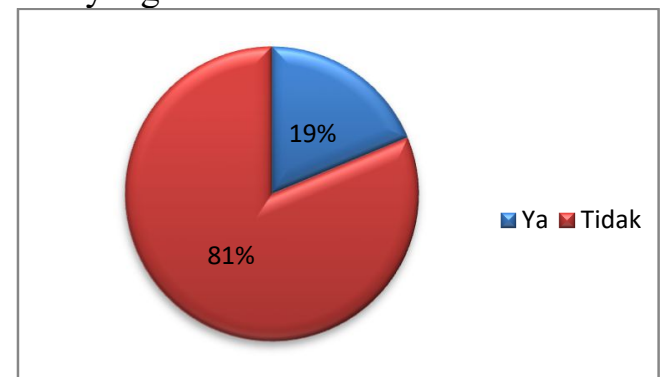

Gambar 3. Keberadaan Tenaga Kerja Ahli/Koki pada Unit Industri Kuliner

Sebanyak 18 unit industri kreatif kuliner online memiliki tenaga kerja ahli berupa koki yang berperan penting dalam proses produksi karena memerlukan ilmu pengetahuan atau pengalaman khusus untuk menghasilkan suatu produk kuliner tertentu, seperti inovasi healthy food. Kualitas tenaga kerja dapat diukur berdasar tingkat pendidikannya. Berikut merupakan jumlah unit industri kreatif kuliner online berdasar tingkat pendidikan tenaga kerja.

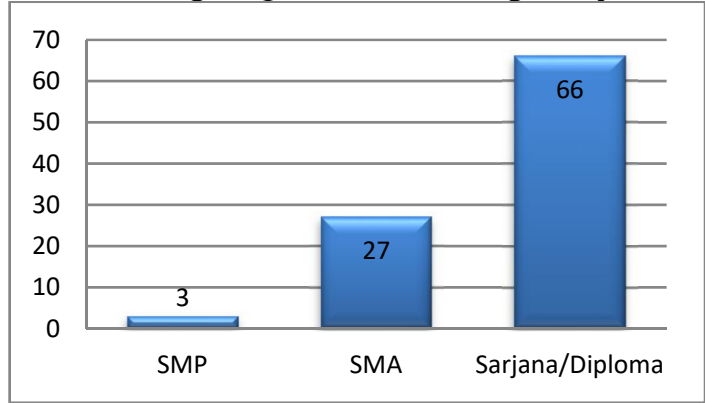

Gambar 4. Jumlah Industri Kreatif Kuliner Online berdasar Tingkat Pendidikan Tenaga Kerja

Tingkat pendidikan tenaga kerja industr kuliner sebagian besar berada pada level sarjana atau diploma yang sebanyak 66 tenaga kerja. Terkait dengan tingkat pendidikan pelaku industri ini, pemerintah dan akademisi telah mengadakan pelatihan terkait upaya pengelolaan bahan baku produksi serta upaya peningkatan kualitas dan kapabilitas sumber daya manusia. Namun masih terdapatnya permasalahan seperti kurangnya tenaga yang efisien dalam mengolah bahan baku, keterbatasan alat pendukung/ teknologi, penurunan kualitas bahan produksi, dan ketersediaan bahan baku terbatas menjadi hal-hal yang harus diatasi dalam pengembangan ke depan.

\section{Aspek Distribusi}

Jaringan distribusi produk kuliner online meliputi lokal (Malang Raya), nasional, dan internasional. Berikut diagram wilayah distribusi produk kuliner online.

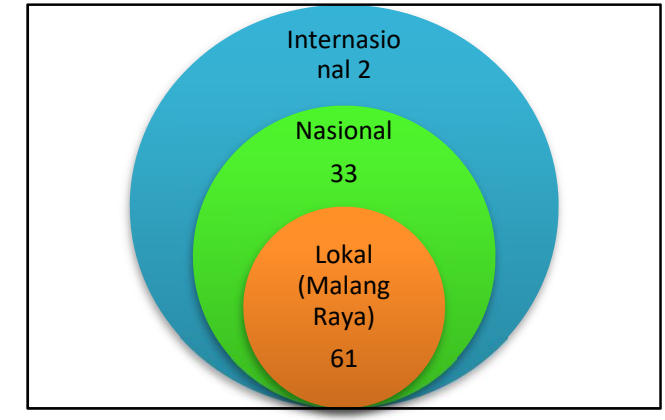

Gambar 5. Jaringan Distribusi Industri Kreatif Kuliner Online

Lebih dari $50 \%$ dari keseluruhan pelaku kuliner online hanya memasarkan produknya pada wilayah lokal Malang karena produknya merupakan jenis produk yang tidak tahan lama (produk basah). Sementara itu, sebanyak 33 pelaku kuliner online telah mendistribusikan 
produk kulinernya mencapai cakupan nasional, seperti ke Jakarta, Balikpapan, Banjarmasin, Semarang, dan lainnya. Mayoritas pelaku industri kreatif kuliner ini menggunakan teknologi yang tertentu dalam proses produksi maupun pengemasannya sehingga produk yang dihasilkan lebih tahan lama dan dapat didistribusikan dalam jarak yang jauh tanpa mengurangi cita rasa serta kualitas produknya. Kemudian terdapat 2 industri kreatif kuliner online yang sudah mampu mendistribusikan/ memasarkan produknya secara internasional, yaitu ke Hongkong, Sydney, Kuala Lumpur, Tokyo, Dubai, Penang, serta Jedah. Hal ini tentu saja menjadi potensi yang besar dalam pengembangan industri kreatif kuliner online di Kota Malang ini.

Dalam sistem distribusi produk, sebanyak $65 \%$ atau 62 unit industri kreatif kuliner online menggunakan jasa pengiriman barang. Berikut diagram yang menggambarkan jenis jasa pengiriman barang yang digunakan oleh unit industri kreatif kuliner online.

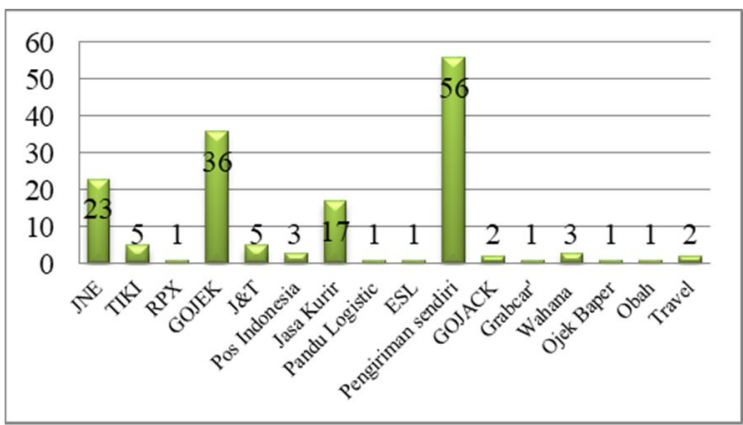

Gambar 6. Jenis Jasa Pengiriman yang Digunakan

Keberadaan jasa pengiriman barang di Kota Malang yang cukup populer saat ini adalah jasa ojek online. Adanya ojek online ini dinilai menguntungkan karena mereka dapat bekerjasama dalam mempromosikan sekaligus mendistribusikan produk milik pelaku industri kuliner. Namun, keberadaan jasa ojek online ini juga dapat dinilai sebagai pesaing usaha karena mempromosikan dan melayani usaha kuliner yang sudah besar, seperti unit kuliner fast food.

\section{Aspek Pemasaran}

Target pasar untuk industri kreatif kuliner online ini terdiri dari 3 segmen, yaitu pekerja, masyarakat umum pada acara besar/event, dan pelajar/mahasiswa.

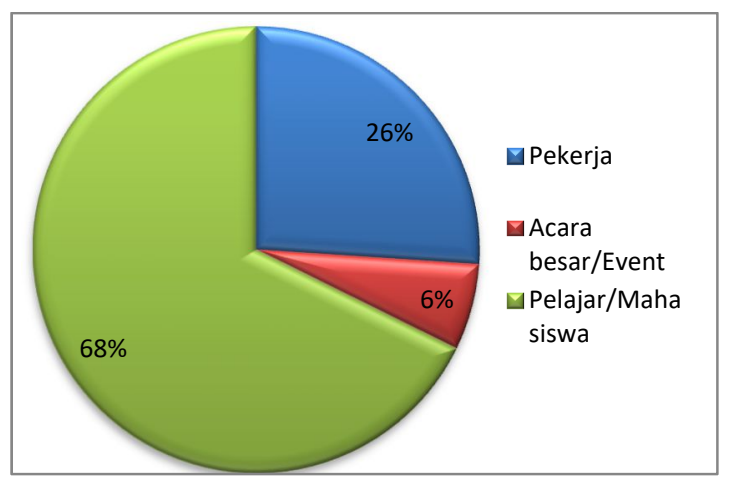

Gambar 7. Segmen Pasar Industri Kreatif Kuliner Online Kota Malang

Sebanyak $68 \%$ atau 65 unit industri kreatif kuliner online memiliki target pasar yaitu pelajar/mahasiswa dengan jenis produk makanan yang banyak dipilih adalah dessert. Jenis makanan tersebut dinilai cocok untuk dipasarkan kepada pelajar/mahasiswa karena harga produk yang murah dan mudah dijangkau. Mayoritas kuliner online tersebut berlokasi di sekitar pusatpusat pendidikan di Kota Malang, karena memudahkan dalam proses distribusi/pemasaran produk. Kemudian sekitar 26\% atau sebanyak 25 unit industri kreatif kuliner online memilih segmentasi pasar berupa pekerja dengan jenis produk yang dipilih adalah makanan Indonesia, makanan Asia, dan makanan barat (western food) dengan range harga yang ditawarkan relatif lebih tinggi/mahal. Kemudian sebanyak 6 unit industri kreatif kuliner online yang memilih/membididik acara besar/event sebagai target pasar yang utama. Industri kreatif kuliner dengan pangsa pasar tersebut lebih banyak menjual produknya pada acara-acara besar/event yang banyak diadakan di Kota Malang seperti bazar kuliner.

Dalam hal ini, keberadaan media online yang semakin merambah dan populer di berbagai kalangan masyarakat dan saat ini dapat dimanfaatkan untuk berbagai kegiatan komersial yang lebih efektif, efisien, dan tidak membutuhkan modal yang besar. Berikut diagram platform media online yang digunakan dalam pemasaran produk kuliner.

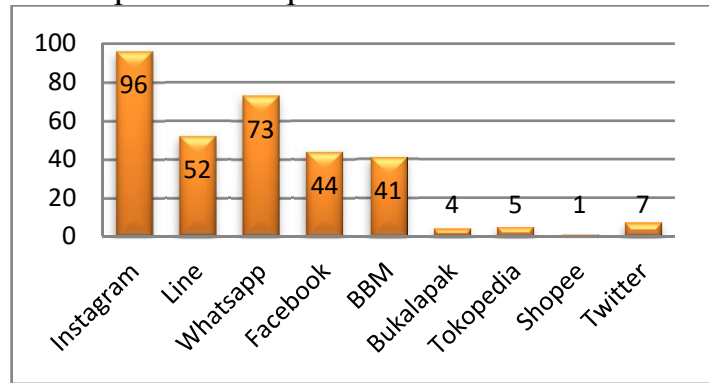

Gambar 8. Jenis Media dalam Pemasaran Produk Kuliner Online

Jenis platform media online yang paling banyak digunakan oleh pelaku kuliner online adalah platform instagram yang mencapai jumlah 96 
pengguna. Adapun jenis platform media online dalam pemasaran yang paling jarang digunakan adalah aplikasi jual beli online seperti Tokopedia, Bukalapak, dan Shopee karena mayoritas produk yang dihasilkan hanya dipasarkan di dalam area Kota Malang, sedangkan cakupan pasar pada aplikasi jual beli online tersebut cukup luas (nasional/internasional), sehingga dinilai kurang prospektif dalam kegiatan pemasaran produk kuliner.

\section{Analisis Aktor Quadruple Helix}

Aktor yang memiliki peran paling besar dalam upaya pengembangan industri kreatif kuliner online di Kota Malang saat ini adalah Dinas Perindustrian dan Perdagangan Kota Malang serta aktor Akademisi. Disperindag Kota Malang memiliki peran yang cukup penting terutama dalam perumusan kebijakan terkait pengembangan industri kreatif yang mengacu pada Roadmap pengembangan industri kreatif yang disusun oleh Badan Perencanaan, Penelitian, dan Pengembangan Kota Malang. Selain itu, Disperindag juga berperan dalam pelaksanaan kegiatan pelatihan kepada pelaku industri kreatif yang ada di Kota Malang, seperti pada UKM maupun masyarakat yang ingin memulai sebuah usaha kreatif. Kegiatan pelatihan tersebut membutuhkan bantuan dari Akademisi, seperti ahli di bidang product marketing, product development, manajemen usaha, dan ahli teknologi pengolahan pangan.

Kemudian terdapat aktor yakni Komunitas Malang Kuliner memiliki peran besar sebagai wadah atau platform bagi pelaku industri kreatif kuliner berbasis media online di Kota Malang untuk melakukan sharing produk, inovasi usaha, mengadakan kegiatan bazar kuliner, bakti sosial, dan bakti sosial. Selain itu, komunitas ini mempunyai anggota yang paling banyak dibandingkan dengan ketiga komunitas lainnya. Berikut diagram peran dan hubungan antar aktor dalam quadruple helix industri kreatif kuliner online Kota Malang.

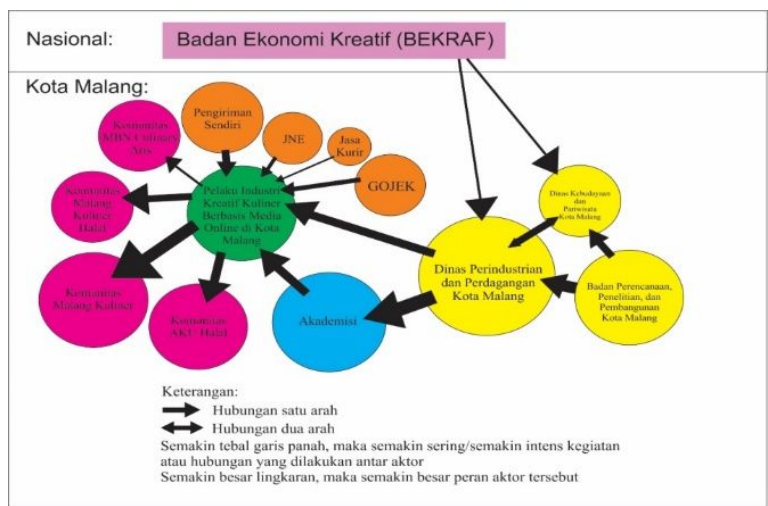

Gambar 9. Analisis Aktor Industri Kreatif Kuliner Online Kota Malang

\section{Pergeseran Paradigma Perkembangan Industri Kreatif Kuliner}

Pergeseran paradigma perkembangan industri kreatif kuliner ini diperoleh dari rumusan hasil pandangan aktor dalam quadruple helix dan sintesa analisis PEST.

Tabel 2. Pergeseran Paradigma Industri Kreatif Kuliner Kota Malang

\begin{tabular}{|c|c|c|}
\hline $\begin{array}{l}\text { Pergeseran } \\
\text { Paradigma }\end{array}$ & Kondisi Dahulu & Kondisi Sekarang \\
\hline Distribusi & $\begin{array}{l}\text { Proses distribusi } \\
\text { barang } \\
\text { menggunakan moda } \\
\text { transportasi } \\
\text { sederhana dengan } \\
\text { jangkauan distribusi } \\
\text { yang tidak jauh/luas }\end{array}$ & $\begin{array}{lr}\text { Munculnya } & \\
\text { teknologi } & \text { baru } \\
\text { berupa smartphone, } & \text { sehingga muncul } \\
\text { beragam } & \text { aplikasi } \\
\text { jasa } & \text { untuk } \\
\text { distribusi } & \text { atau } \\
\text { pemesanan } & \\
\text { makanan } & \text { secara } \\
\text { online. } & \end{array}$ \\
\hline $\begin{array}{l}\text { Promosi dan } \\
\text { Pemasaran }\end{array}$ & $\begin{array}{lr}\text { Kegiatan } & \text { promosi } \\
\text { dan } & \text { pemasaran } \\
\text { produk dilakukan } & \text { langsung } \\
\text { secara } & \text { lan } \\
\text { dengan } & \text { bertatap } \\
\text { muka } & \text { dengan } \\
\text { konsumen atau } \\
\text { melalui media cetak } \\
\text { berupa pamflet, } \\
\text { brosur, baliho, dan } \\
\text { lain lain }\end{array}$ & 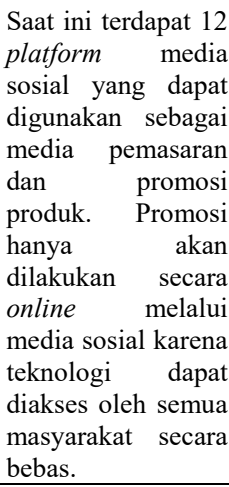 \\
\hline
\end{tabular}

\section{Value Proposition}

Berdasar pergeseran paradigma yang terjadi pada industri kreatif kuliner, karakteristik industri dan hasil dari pendapat aktor dalam quadruple helix, maka kesimpulan yang dapat dirumuskan untuk penentuan value proposition industri kreatif kuliner online.

Tabel 3. Value Proposition Industri Kreatif Kuliner Online Kota Malang

\begin{tabular}{ll}
\hline \multicolumn{1}{c}{ Proses } & \multicolumn{1}{c}{ Keterangan } \\
\hline Distribusi & Pelaku kuliner online menggunakan jasa \\
& pengiriman barang secara online seperti JNE, \\
& TIKI, Wahana, dan GOJEK. Dari proses \\
& distribusi tersebut, value proposition lebih \\
& mengarah pada operational excellence. \\
Promosi & Kegiatan promosi yang dilakukan juga \\
& menggunakan akun media sosial sepeti \\
& instagram, youtube, dan facebook karena \\
& lebih efisien. Oleh karena itu, value \\
& proposition lebih mengarah pada operational \\
& excellence. \\
& Kegiatan pemasaran produk dilakukan secara \\
& online karena tidak memerlukan biaya yang \\
& besar seperti kegiatan pemasaran secara \\
& offline. Dari segi pemasaran, maka value \\
& proposition lebih mengarah pada operational \\
& excellence.
\end{tabular}




\section{Visi Misi Industri Kreatif Kuliner Online di Kota Malang}

Berdasar hasil dari analisis dan penentuan value proposition yaitu operational excellence, maka diperoleh visi dan misi sebagai berikut:

Visi

"Mengembangkan Industri Kreatif Kuliner Online yang Berorientasi pada Efisiensi Distribusi, Pemasaran, dan Promosi secara Online"

Misi

Adapun misi dalam mewujudkan visi pengembangan industri kreatif kuliner berbasis media online di Kota Malang adalah sebagai berikut:

1. Meningkatkan efisiensi distribusi produk kuliner online melalui kerjasama dengan jasa delivery online.

2. Mengembangkan efisiensi jaringan pemasaran dan promosi online untuk memperluas pangsa pasar sampai tingkat internasional.

3. Meningkatkan kapabilitas sumber daya manusia yang berdaya guna untuk mendukung efisiensi pemasaran dan promosi melalui kerjasama antar aktor.

\section{Strategi Pengembangan Industri Kreatif Kuliner Berbasis Media Online Kota Malang}

Untuk mewujudkan visi dan misi tersebut, strategi pengembangan industri kreatif kuliner berbasis media online di Kota Malang meliputi:

1. Meningkatkan kegiatan distribusi produk melalui kerjasama dengan perusahaan penyedia jasa delivery order online.

2. Meningkatkan promosi yang mampu memperluas pangsa pasar kuliner online hingga keluar negeri.

3. Meningkatkan kegiatan pemasaran dan promosi produk secara online melalui kerjasama dengan pihak pemerintahan.

4. Meningkatkan kegiatan pemasaran dan promosi produk industri kreatif kuliner online melalui kerjasama dengan komunitas kuliner online.

5. Membangun linkage dengan industri kreatif subsektor lain untuk menunjang kegiatan pemasaran dan promosi produk kuliner online.

6. Meningkatkan pembiayaan pemasaran dan promosi produk industri kreatif kuliner online.

7. Meningkatkan pembiayaan pemasaran dan promosi produk industri kreatif kuliner online.

\section{Rencana Aksi Pengembangan Industri Kreatif Kuliner Online Kota Malang}

Rencana aksi disusun berdasarkan strategi industri kreatif kuliner online yang dipadukan dengan kondisi SWOT yang ada pada kondisi saat ini. Berikut rencana aksi industri kreatif kuliner online di Kota Malang.

1. Mendaftarkan produk industri kreatif kuliner online pada semua aplikasi delivery order yang ada di Kota Malang.

2. Kerjasama dengan jasa delivery order untuk mendapatkan harga khusus dalam kegiatan distribusi produk kuliner online.

3. Meningkatkan intensitas pemasaran dan promosi produk di semua platform sosial media dan e-commerce.

4. Meningkatkan penggunaan jasa optimalisasi kegiatan promosi melalui Search Engine Optimalization, Google Adwords, Facebook Ads, dan Market Place.

5. Mengadakan kerjasama dengan media partner online dan media jurnalistik populer untuk memperluas jaringan promosi produk di media sosial.

6. Mengadakan kegiatan pemasaran dan promosi produk industri kreatif kuliner online melalui media sosial dan website resmi milik pemerintah.

7. Mengenalkan produk industri kreatif kuliner online kepada konsumen melalui promosi yang dilakukan oleh komunitas kuliner online dan akun promosi kuliner online di media sosial.

8. Mengadakan kegiatan gathering, sharing, dan event promosi produk dengan komunitas kuliner online di Malang Art Center.

9. Mengadakan kerjasama dengan industri kreatif subsektor desain grafis untuk pembuatan logo produk, desain kemasan, dan desain iklan untuk promosi.

10.Mengadakan kerjasama dengan industri kreatif subsektor games untuk membuat games bertema kuliner online sebagai media promosi.

11.Kerjasama dengan komunitas kuliner online untuk mengadakan event pameran atau bazar.

12.Kerjasama dengan aplikasi online untuk memasang iklan games kuliner.

13. Kerjasama dengan perusahaan swasta untuk medapatkan pembiayaan dalam kegiatan pemasaran dan promosi produk.

14.Mengadakan pelatihan sistem pemasaran dan promosi melalui media sosial dan e-commerce melalui kerjasama dengan akademisi.

15.Kerjasama dengan para ahli sebagai pelatih dalam kegiatan pelatihan pengembangan pemasaran dan promosi secara online. 


\section{PENUTUP}

\section{Kesimpulan}

Visi industri kreatif kuliner online yaitu

"Mengembangkan Industri Kreatif Kuliner

Online yang Berorientasi pada Efisiensi Produksi dan Pemasaran Online"

Adapun misi pendukung visi tersebut adalah:

1. Menyediakan mesin produksi kuliner yang tepat guna untuk meningkatkan efisiensi produksi melalui kerjasama dengan akademisi

2. Meningkatkan kapabilitas sumber daya manusia yang berdaya guna untuk mendukung efisiensi produksi dan pemasaran melalui kerjasama antar aktor

3. Mengembangkan efisiensi jaringan pemasaran online untuk memperluas pangsa pasar sampai tingkat internasional

Strategi pengembangan industri kreatif kuliner online meliputi:

1. Memfasilitasi pelaku industri kreatif kuliner online dengan mesin produksi kuliner yang digunakan secara komunal

2. Menyediakan tempat untuk penggunaan mesin produksi kuliner bagi pelaku industri kreatif kuliner online

3. Menyediakan media untuk kerjasama dengan pihak swasta

4. Meningkatkan kuantitas tenaga ahli di bidang industri kreatif kuliner online

5. Meningkatkan kegiatan pelatihan tematik terkait pengembangan industri kreatif kuliner online

6. Meningkatkan pangsa pasar kuliner online hingga keluar negeri

7. Meningkatkan kegiatan pemasaran dan promosi produk secara online melalui kerjasama dengan pihak pemerintahan

8. Meningkatkan kegiatan pemasaran dan promosi produk industri kreatif kuliner online melalui kerjasama dengan komunitas kuliner online

9. Membangun linkage dengan industri kreatif subsektor lain untuk menunjang kegiatan pemasaran dan promosi produk kuliner online

10. Meningkatkan pembiayaan pemasaran dan promosi produk industri kreatif kuliner online

Dari 10 strategi tersebut dianalisis menggunakan analisis SWOT Dan dihasilkan 22 rencana aksi pengembangan industri kreatif kuliner online di Kota Malang

\section{DAFTAR PUSTAKA}

Instruksi Presiden (Inpres) Nomor 6 Tahun 2009 tentang Pengembangan Ekonomi Kreatif
Brown, Amy. 2015. Understanding Food Principles and Preparation. USA: Cengage Learning

Chen, Hayyana, Budi Sutomo. 2015. Koleksi Resep Chinese Food. Jakarta Selatan: PT Kawan Pustaka

Handayani, Titin Hera Widi, Marwanti. 2011. Pengolahan Makanan Indonesia. Yogyakarta.

Hermawan, Agus. 2012. Komunikasi Pemasaran. Jakarta: Erlangga.

Mulyana, Sutapa. 2014. Peningkatan Kapabilitas Inovasi, Keunggulan Bersaing, dan Kinerja melalui Pendekatan Quadruple Helix: Studi pada Industri Kreatif Sektor Fashion. Jurnal Manajemen Tenologi Vol.13, No.3.

Natasha, Priscilla, Devie. 2013. Analisa Pengaruh Strategic Planning terhadap Keunggulan Bersaing dan Kinerja Perusahaan. Business Accounting Review. Vol. 1, No. 2.

Nugroho, Cahyo Adhi. Analisis Profil Industri Knalpot di Purbalingga, Kabupaten Purbalingga.

Nurmanisa, Aisy, Wilopo, dkk. 2016. Analisis Customer Segment, Channels, dan Cutsomer Relationship dalam Pembentukan Value Proposition di Starbucks Coffee. Jurnal Administrasi Bisnis. Vol. 34, No.1.

Rahmasari, Lisda. 2011. Pengaruh Supply Chain Management terhadap Kinerja Perusahaan dan Keunggulan Bersaing (Studi Kasus pada Industri Kreatif di Provinsi Jawa Tengah). Majalah Ilmiah Informatika. Vol. 2, No. 3.

Sedarmayanti, Syarifudin. 2002. Metodologi Penelitian. Bandung: Mandar Maju.

Soekresno. 2000. Manajemen Food and Beverage Edisi ke II. Jakarta: PT. Gramedia Pustaka

Suryana. 2013. Ekonomi Kreatif Ekonomi Baru: Mengubah Ide dan Menciptakan Peluang. Jakarta: Salemba Empat.

Team FME. 2013. PESTEL Analysis Strategy Skills. Free Management Ebooks.

Tjiptono, Fandy, dkk. 2008. Perencanaan Strategik. Yogyakarta: ANDI Yogyakarta. Utama 